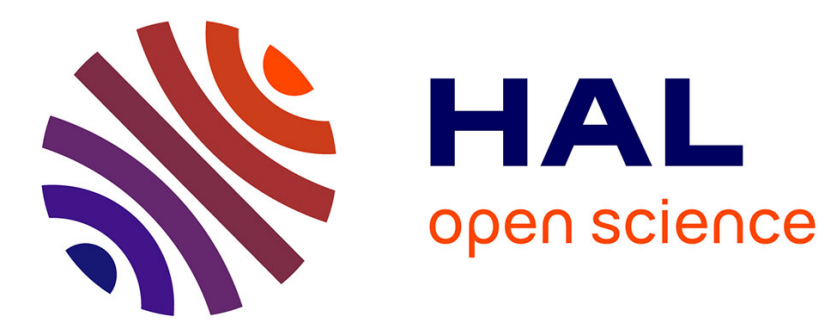

\title{
High Temperature Removal of H2S over Iron Oxide Supported on SiC Sorbent
}

\author{
C. Pham-Huu, C. Estournes, B. Heinrich, C. Crouzet, M. Ledoux
}

\section{To cite this version:}

C. Pham-Huu, C. Estournes, B. Heinrich, C. Crouzet, M. Ledoux. High Temperature Removal of H2S over Iron Oxide Supported on SiC Sorbent. Journal de Physique IV Proceedings, 1997, 07 (C1), pp.C1-677-C1-678. 10.1051/jp4:19971277 . jpa-00254989

\section{HAL Id: jpa-00254989 https://hal.science/jpa-00254989}

Submitted on 1 Jan 1997

HAL is a multi-disciplinary open access archive for the deposit and dissemination of scientific research documents, whether they are published or not. The documents may come from teaching and research institutions in France or abroad, or from public or private research centers.
L'archive ouverte pluridisciplinaire HAL, est destinée au dépôt et à la diffusion de documents scientifiques de niveau recherche, publiés ou non, émanant des établissements d'enseignement et de recherche français ou étrangers, des laboratoires publics ou privés. 


\title{
High Temperature Removal of $\mathrm{H}_{2} \mathrm{~S}$ over Iron Oxide Supported on SiC Sorbent
}

\author{
C. Pham-Huu, C. Estournes*, B. Heinrich, C. Crouzet and M.J. Ledoux \\ Laboratoire de Chimie des Matériaux Catalytiques, ECPM, University Louis Pasteur, 1 rue Blaise \\ Pascal, 67008 Strasbourg cedex, France \\ * Groupe des Matériaux Inorganiques, ECPM, University Louis Pasteur, 1 rue Blaise Pascal, 67008 \\ Strasbourg cedex, France
}

\begin{abstract}
.
A new material, $\mathrm{Fe}_{2} \mathrm{O}_{3}$ supported on high specific surface area $\mathrm{SiC}$, is very efficient for the $\mathrm{H}_{2} \mathrm{~S}$ removal from hot exhaust gas. The specific properties of the silicon carbide allows a very large number of sulfidation/regeneration cycles.
\end{abstract}

\section{INTRODUCTION}

$\mathrm{H}_{2} \mathrm{~S}$ is produced in large amounts from the gasification of coal and also from many other industrial processes: pyrolysis, cracking, hydrocracking and hydrotreatment. The purification of the exit gas to remove $\mathrm{H}_{2} \mathrm{~S}$ is essential prior to subsequent utilization. The solid sorbents used for high temperature $\mathrm{H}_{2} \mathrm{~S}$ removal are widely investigated in the literature [1-3] which mainly deals with calcium oxide, zinc oxide, zinc ferrite or zinc titanate in an unsupported form. However, during the absorption and regeneration cycles a contraction (sulfidation) and an expansion (oxidative regeneration) occur and lead to sorbent deterioration and sintering. This is followed by a pressure drop accross the bed due to the attrition of the material, reducing its $\mathrm{H}_{2} \mathrm{~S}$ removal capacity. These phenomena can be avoided by replacing the unsupported sorbent by a supported one $[4,5]$. Silicon carbide is well known to be an efficient heat conductor, with a high thermal resistance and a high mechanical strength, which can be efficient for the use of this material as a support for high temperature $\mathrm{H}_{2} \mathrm{~S}$ removal. In addition, silicon carbide is a chemically inert material which cannot interact with the active phase by destroying its sorbent capacity as is the case for alumina support [5].

The aim of this article is to report the preparation, the characterization and the performance of $\mathrm{Fe}_{2} \mathrm{O}_{3} / \mathrm{SiC}_{\text {solid }}$ sorbent for high temperature $\mathrm{H}_{2} \mathrm{~S}$ removal and its stability as a function of absorption-regeneration cycles.

\section{EXPERIMENTAL}

The silicon carbide is synthesized by a gas-solid reaction, under dynamic vacuum, between a vapor of SiO, generated by a mixture $\mathrm{Si}+\mathrm{SiO}_{2}$, and a high surface area activated charcoal as described in detail elsewhere [6]. The SiC obtained by this method has a surface area of $25 \mathrm{~m}^{2} \mathrm{~g}^{-1}$. The sorbent is prepared by incipient wetness impregnation of the SiC with an aqueous solution of iron nitrate. After impregnation the sorbent is dried at room temperature for $12 \mathrm{~h}$ and then calcinated at $400^{\circ} \mathrm{C}$ for $2 \mathrm{~h}$.

The $\mathrm{H}_{2} \mathrm{~S}$ removal experiment is performed in a flow micropilot working at atmospheric pressure and on a fixed bed. The composition of the reactant mixture is constant and contains $\mathrm{H}_{2} \mathrm{~S}(0.5 \mathrm{vol} . \%)$ and balance helium. The products from the reactor unit are analyzed on-line by gas chromatography, which allows the separation of $\mathrm{H}_{2} \mathrm{~S}, \mathrm{H}_{2} \mathrm{O}$ and $\mathrm{SO}_{2}$. The regeneration is performed at $650^{\circ} \mathrm{C}$ in flowing air for $2 \mathrm{~h}$.

\section{RESULTS AND DISCUSSION}

The amount of iron oxide measured by atomic absorption spectroscopy is $15 \mathrm{wt} \%$. The surface area of the calcined sorbent $\left(\mathrm{Fe}_{2} \mathrm{O}_{3} / \mathrm{SiC}\right.$ ) measured by $\mathrm{N}_{2}$ adsorption is $45 \mathrm{~m}^{2} \mathrm{~g}^{-1}$ with the pore size distribution centered between 4 and $10 \mathrm{~nm}$. The iron oxide is finely and homogeneously dispersed on the support and no diffraction lines corresponding to iron oxide are observed. The presence of small iron oxide particles on the sorbent is also confirmed by magnetic measurements (Fig. 1) which show the presence of magnetic compounds and the lack of the magnetization saturation (existence of small magnetic particles). 
The $\mathrm{H}_{2} \mathrm{~S}$ removal capacity obtained at $400^{\circ} \mathrm{C}$ on $\mathrm{Fe}_{2} \mathrm{O}_{3} / \mathrm{SiC}$ is presented in $\mathrm{Fig}$. 2. The $\mathrm{H}_{2} \mathrm{~S}$ removal is almost complete during the first 300 minutes of absorption and only water is detected at the exit of the reactor. At that point, the concentration of $\mathrm{H}_{2} \mathrm{~S}$ starts to rise rapidly to the inlet value of around $6200 \mathrm{ppmv}$ of $\mathrm{H}_{2} \mathrm{~S}$. The sulfur capacity breakthrough is around $90-95 \%$ of the theoretical capacity assuming the transformation $\mathrm{Fe}_{2} \mathrm{O}_{3} \rightarrow \mathrm{FeS}$.

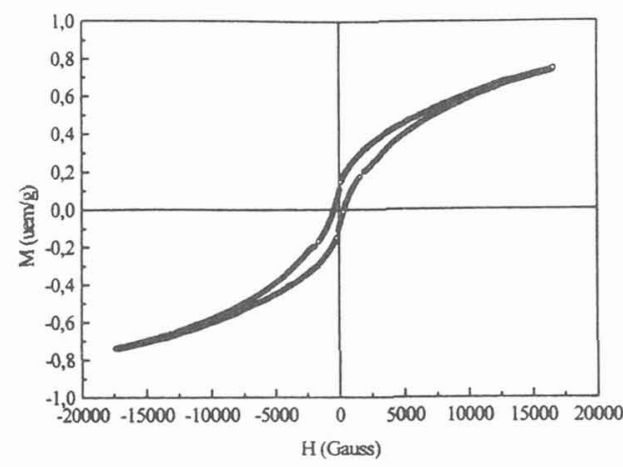

Figure 1: Magnetic measurement of the fresh sorbent after calcination at $400^{\circ} \mathrm{C}$ for $2 \mathrm{~h}$.

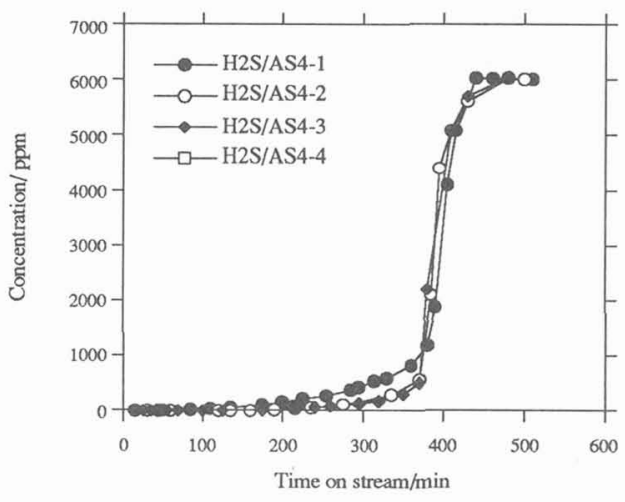

Figure 2: $\mathrm{H}_{2} \mathrm{~S}$ removal capacity as a function of the sulfidation-regeneration cycle on the $\mathrm{Fe}_{2} \mathrm{O}_{3} / \mathrm{SiC}$ sorbent at $400^{\circ} \mathrm{C}$ and with a space velocity of $1200 \mathrm{~h}^{-1}$.

The high capacity for $\mathrm{H}_{2} \mathrm{~S}$ absorption is attributed to the high surface area of the sorbent which allows a high surface contact between $\mathrm{H}_{2} \mathrm{~S}$ and the iron oxide. The XRD pattern of the sorbent after absorption shows the presence of FeS $\mathrm{S}_{\mathrm{x}}$ and $\mathrm{a}$ small amount of $\mathrm{FeS}_{2}$ which means that some sintering occured during the absorption. This phenomenon is correlated by a concomitant decrease in the sorbent surface area from 45 to $27 \mathrm{~m}^{2} \mathrm{~g}^{-1}$. The decrease of the surface area during sulfidation has already been reported by Groot [7] and is attributed to the structural alteration of the starting oxide. The sorbent is regenerated in air at $650^{\circ} \mathrm{C}$ for $2 \mathrm{~h}$. After regeneration all the iron sulfide is oxidized into iron oxide as observed by the XRD characterization and only $\mathrm{SO}_{2}$ is detected at the exit of the reactor. The surface area decreased slightly from 27 to $24 \mathrm{~m}^{2} \mathrm{~g}^{-1}$. The $\mathrm{H}_{2} \mathrm{~S}$ removal capacity obtained on the regenerated sorbent is identical to that obtained on the fresh one.

The stability of the sorbent as a function of the absorption and regeneration cycles is reported in Fig. 2. The reactor is flushed with helium between reactions. As shown from the results no change in the $\mathrm{H}_{2} \mathrm{~S}$ removal capacity occured after four cycles. The surface area of the sorbent after the set of experiments decreased slightly to $17 \mathrm{~m}^{2} \mathrm{~g}^{-1}$ after the second cycle and then remained unchanged for the rest of the experiments. The high stability of the sorbent is attributed to the high thermal conductivity of the silicon carbide support which prevents the formation of hot spots during the regeneration, hot spots which can be responsible for a drastic sintering of the active phase.

\section{Acknowledgements}

The present work is supported by the Pechiney Company. The magnetic measurements were performed in the Groupe des Materiaux Inorganiques (IPCMS, UMR 46 of the CNRS).

\section{References}

[1] Fenouil, L. A. Ind. Eng. Chem. Res. 33 (1994) 265-272.

[2] Lew S., Sarofin A. and Flytzani-Stephanopoulos M. Ind. Eng. Chem. Res. 31 (1991) 1890-1899.

[3] Ayala R. E. and Marrsch D. W. Ind. Eng. Chem. Res. 30 (1991) 55-60.

[4] Patrick V., Gavalas G. R., Flytzani-Stephanopoulos M. and Jothimurugesan K. Ind. Eng. Chem. Res. 28 (1989) 931-940.

[5] Patrick V., Gavalas G. R. and Sharma P. K. Ind. Eng. Chem. Res. 32 (1993) 519-532.

[6] Ledoux M. J., Hantzer S., Guille J. and Dubots D. U. S. Patent No. 4914070.

[7] Groot C. K. PhD Dissertation, University of Technology Eindhoven, 1984. 